\title{
HAEMATOLOGICAL AND BIOCHEMICAL PROFILES DURING THE PUERPERIUM IN DAIRY COWS - SHORT COMMUNICATION
}

\author{
Renan B. PAIANO ${ }^{*}$, Fábio C. LAHR ${ }^{2}$, Lucas S. B. Silva ${ }^{2}$, Diego S. MARQUeS ${ }^{2}$, \\ Catia A. FERrEIRA ${ }^{3}$, Daniela B. BIRGEL ${ }^{2}$, Rafael S. BisINOTTO ${ }^{4}$ and \\ Eduardo H. BIRGEL JUNIOR ${ }^{2}$
}

\begin{abstract}
${ }^{1}$ Department of Anatomy of Domestic and Wild Animals, School of Veterinary Medicine and Animal Sciences, University of São Paulo, 05508270 São Paulo, Brazil; ${ }^{2}$ Department of Veterinary Medicine, Faculty of Animal Science and Food Engineering, University of

São Paulo, Pirassununga, Brazil; ${ }^{3}$ University Center Anhanguera, Leme, Brazil;

${ }^{4}$ Department of Animal Science, Florida University, Gainesville, Florida, USA
\end{abstract}

(Received 3 January 2019; accepted 31 July 2019)

\begin{abstract}
The main aim of the current study was to assess the prevalence of anaemia in Holstein dairy cows during the puerperium, and the haematological and biochemical profile of dairy cows with and without anaemia. The study was conducted in seven dairy herds in São Paulo State, Brazil. The evaluated sample comprised a total of 336 Holstein cows. Blood samples were collected at postpartum day $25 \pm 3$. Haematological analysis included white blood cell, red blood cell and platelet count, haematocrit value, haemoglobin concentration, mean corpuscular volume, mean corpuscular haemoglobin and mean corpuscular haemoglobin concentration. The biochemical profile encompassed cholesterol, non-esterified fatty acids, $\beta$-hydroxybutyrate, albumin, globulin, fibrinogen, calcium and total bilirubin concentrations. The prevalence of anaemia was $16.3 \%$ in all herds, and this was not affected by clinical diseases, milk production, parity and body score condition. Moreover, anaemic cows had lower red blood cell count, haematocrit, haemoglobin, serum cholesterol and calcium concentrations and higher white blood cell and platelet counts, mean corpuscular haemoglobin, red cell distribution width, non-esterified fatty acids, $\beta$-hydroxybutyrate, fibrinogen and globulin concentrations when compared with non-anaemic cows. The results indicate changes in energy balance and an inflammatory process in anaemic cows.
\end{abstract}

Key words: Biochemical profile, anaemia, puerperium, dairy cows

Anaemia is the main disorder involving red blood cells in ruminants, mostly occurring in three aetiological forms: aplastic, haemorrhagic and haemolytic (Radostits et al., 2007), although deficiency and inflammatory anaemia in calves are also not uncommon (Lindt and Blum, 1994).

*Corresponding author; E-mail: renanpaiano@hotmail.com; Phone: 0055 (19) 3565-4200 
The main causes of anaemia in cattle are haemolysis and nutritional deficiency. Haemolysis may be a physiological phenomenon when it involves the breakdown of aged red blood cells, or it may be a pathological process in the case of parasitism caused by worms, ticks and intra-erythrocytic parasites such as Babesia bovis, B. microti, Anaplasma centrale and A. marginale (Souza et al., 2013; Muntean et al., 2018). The causes linked to nutritional deficiency comprise iron, phosphorus, cobalt and copper deficiency (Radostits et al., 2007).

No study has reported the prevalence of anaemia in postpartum dairy cows so far. Therefore, the aims of the current study were to characterise the prevalence of anaemia within the first $25 \pm 3$ postpartum days, as well as to investigate the biochemical and haematological profiles of dairy cows with and without anaemia.

The experiment was approved by the Ethics Committee of the School of Veterinary Medicine and Animal Sciences, University of São Paulo, São Paulo, Brazil (approval number: 8022150216/2018).

The sample size was determined according to the formula given by Thrusfield (2005). We estimated a sample size of 336 cows assuming an anaemia prevalence of $32.2 \%$ from the previous report, as well as $95 \%$ confidence level and $5 \%$ precision.

In the current study 336 Holstein cows (mean lactation number: $2.29 \pm$ 0.18), from seven dairy farms located in São Paulo State, Brazil, were assessed. Cows were diagnosed with anaemia based on values of the erythrogram; the disorder was characterised by a red blood cell $(\mathrm{RBC})$ count, haemoglobin $(\mathrm{Hb})$ concentration and haematocrit $(\mathrm{Ht})$ value lower than $5.0 \times 10^{12} / \mathrm{L}, 8.0 \mathrm{~g} / \mathrm{L}$ and $24 \%$, respectively, as recommended in the literature (Radostits et al., 2007). Cows that had $\mathrm{RBC}$, Ht and $\mathrm{Hb}$ values $\geq 5.0 \times 10^{12} / \mathrm{L}, 8.0 \mathrm{~g} / \mathrm{L}$ and $24 \%$ were classified as non-anaemic.

Blood samples were collected at postpartum day $25 \pm 3$, by means of coccygeal vein puncture, and placed in two tubes. For haematological analysis, blood samples were collected in vacuum glass tubes containing ethylenediaminetetraacetic acid (EDTA) as anticoagulant. For biochemical determinations, blood samples were collected in anticoagulant-free tubes. Blood smears were made immediately after blood collection in order to allow investigating the presence of intra-erythrocytic parasites and to evaluate the characteristics of red blood cells stained with Rosenfeld solution. This evaluation was performed using optical microscopy at a magnification of $100 \times$ as recommended in the literature (Birgel, 1982). All blood samples were transported to the laboratory on ice until centrifugation within $3 \mathrm{~h}$ of blood collection. Blood samples were centrifuged at 2,500 $\times$ $\mathrm{g}$ for $20 \mathrm{~min}$. Serum samples were stored at $-20^{\circ} \mathrm{C}$ until analysed.

Blood analyses comprising the determination of white blood cell (WBC), $\mathrm{RBC}$ and platelet counts, $\mathrm{Hb}, \mathrm{Ht}$, mean corpuscular volume (MCV), mean corpuscular haemoglobin $(\mathrm{MCH})$, mean corpuscular haemoglobin concentration 
(MCHC) and red cell distribution width (RDW) were performed using a veterinary haematology analyser (BC-2800 Vet Mindray), by following specific procedures for bovine samples.

Cholesterol, non-esterified fatty acids (NEFA), $\beta$-hydroxybutyrate (BHBA), albumin, fibrinogen, calcium and total bilirubin (TBIL) concentrations were measured by the use of Randox commercial kits in an automatic biochemistry system (RX Daytona $^{\circledR}$, Randox Laboratories, UK). Globulin concentrations were assumed by subtracting albumin levels from the total protein concentration.

Cows were scored for body condition on a 1 to 5 scale (Ferguson et al., 1994) at the time of blood sampling. The body condition score (BCS) was also categorised as $\leq 2.75$ and $\geq 3.0$ to be used as an explanatory variable. Milk production was measured when the samples were obtained, using the software Alpro ${ }^{\circledR}$. Milk production was also categorised as low $(<30 \mathrm{~L})$, medium $(30$ to $44 \mathrm{~L})$ and high $(\geq 45 \mathrm{~L})$ to be used as an explanatory variable.

Cows were evaluated for metritis on day $10 \pm 5$ postpartum by transrectal palpation. Metritis was defined as a cow having an enlarged uterus with fetid watery red-brown uterine discharge (Sheldon et al., 2009). Endometritis was evaluated at 21 day postpartum by visual inspection using vaginal palpation, mucus was scored on a scale from 0 to 5 as described previously by McDougall et al., (2007), and a score $>2$ was considered positive for endometritis. Mastitis was evaluated during the first three weeks after parturition, diagnosed when the California Mastitis Test was positive (score $>3$ ). Lameness was defined as a cow that stood and walked with arched back and had short strides in one or more legs (lameness score > 2) (Ribeiro et al., 2013).

The analysis was performed using a commercial software (SAS, version 9.3, SAS Institute Inc., Cary, NC). The effects of clinical disease (first versus second versus third or more lactations), BCS ( $\leq 2.75$ versus $\geq 3.00)$, and milk production (low, medium and high) on the prevalence of anaemia were analysed by logistic regression. The means of biochemical and haematological parameters of the groups studied (anaemic vs. non-anaemic) of cows were compared through analysis of variance (ANOVA). The Tukey's test was used to investigate differences between means. Statistical significance level was set at $\mathrm{P}<0.05$.

The overall prevalence of anaemia was $16.36 \%$, which means that 55 out of the 336 cows presented reduced erythrogram values. Among the anaemic cows, $9.1 \%(5 / 55)$ presented severe anaemia (defined by $\mathrm{RBC}$ values $\leq 3.9 \times 10^{12} / \mathrm{L}$, $\mathrm{Hb} \leq 6.1 \mathrm{~g} / \mathrm{L}$ and $\mathrm{Ht} \leq 19.9 \%) ; 30.9 \%$ (17/55) presented moderated anaemia (defined by $\mathrm{RBC}$ values between $4.0-4.4 \times 10^{12} / \mathrm{L}, \mathrm{Hb}$ between $6.2-7.0 \mathrm{~g} / \mathrm{L}$ and $\mathrm{Ht}$ between $20-21.9 \%$ ), and $60 \%$ (33/55) presented mild anaemia (defined by RBC values between $4.5-4.9 \times 10^{12} / \mathrm{L}$, Hb between 7.1-7.9 g/L and $\mathrm{Ht}$ between $22-$ $23.9 \%$ ). The anaemia observed in the animals was normocytic normochromic.

Metritis, endometritis, mastitis and lameness did not influence the prevalence of anaemia $(\mathrm{P}>0.05)$ (Table 1). Parity, BCS, and milk production did not 
affect the prevalence of anaemia $(\mathrm{P}>0.05)$ (Table 2). The RBC count, $\mathrm{Ht}$ value, $\mathrm{Hb}$, cholesterol and calcium concentrations were lower $(\mathrm{P}<0.05)$ in anaemic than in non-anaemic cows. WBC and platelet counts, $\mathrm{MCH}, \mathrm{RDW}$, NEFA, BHBA, globulin and fibrinogen concentrations were higher $(\mathrm{P}<0.05)$ in anaemic cows than in non-anaemic cows (Table 3 ).

\section{Table 1}

Effect of clinical diseases on the prevalence of anaemia in Holstein dairy cows $(n=336)$

\begin{tabular}{lcc}
\hline Diseases & Prevalence of anaemia, $\%$ & P value \\
\hline $\begin{array}{l}\text { Metritis } \\
\text { No }\end{array}$ & $18.6(46 / 247)$ & \\
$\quad$ Yes & $10.1(09 / 89)$ & 0.0679 \\
Endometritis & $17.2(43 / 250)$ & \\
$\quad$ No & $14.0(12 / 86)$ & 0.4840 \\
$\quad$ Yes & & \\
Mastitis & $17.1(52 / 305)$ & 0.2990 \\
$\quad$ No & $09.7(03 / 31)$ & \\
Yes & & \\
Lameness & $15.3(46 / 301)$ & \\
No & $25.7(09 / 35)$ & \\
Yes & & \\
\hline
\end{tabular}

\section{Table 2}

Effect of body condition score, milk production, and parity on the prevalence of anaemia in Holstein dairy cows $(n=336)$

\begin{tabular}{|c|c|c|}
\hline Variable & Prevalence of anaemia \% & $P$ value \\
\hline \multicolumn{3}{|l|}{ Parity $^{1}$} \\
\hline First & $16.67(14 / 84)$ & 0.5993 \\
\hline Second & $14.17(17 / 120)$ & \\
\hline Third or more & $18.18(24 / 132)$ & \\
\hline \multicolumn{3}{|l|}{ Body condition score ${ }^{2}$} \\
\hline$\leq 2.75$ & $16.51(36 / 218)$ & 0.8536 \\
\hline$\geq 3.00$ & $16.10(19 / 118)$ & \\
\hline \multicolumn{3}{|c|}{ Daily milk production $(\mathrm{L})^{3}$} \\
\hline Low $(<30.0)$ & $14.91(17 / 114)$ & 0.3785 \\
\hline Medium (30 to 44$)$ & $20.89(28 / 134)$ & \\
\hline High $(\geq 45.0)$ & $11.36(10 / 88)$ & \\
\hline
\end{tabular}


Table 3

Haematological and biochemical parameters of non-anaemic and anaemic cows $(n=336)$

\begin{tabular}{lrrrr}
\hline Parameter & $\begin{array}{c}\text { Non-anaemic } \\
(\mathrm{n}=281)\end{array}$ & $\begin{array}{c}\text { Anaemic } \\
(\mathrm{n}=55)\end{array}$ & P value & $\begin{array}{c}\text { Reference } \\
\text { values }\end{array}$ \\
\hline $\mathrm{WBC}\left(\times 10^{9} / \mathrm{L}\right)$ & $11.94 \pm 0.28$ & $17.30 \pm 0.57$ & $0.019^{*}$ & $4.0-12.0^{* *}$ \\
$\mathrm{RBC}\left(\times 10^{12} / \mathrm{L}\right)$ & $5.65 \pm 0.09$ & $4.44 \pm 0.15$ & $<0.0001^{*}$ & $5.0-10.0$ \\
$\mathrm{Ht}(\%)$ & $28.44 \pm 0.37$ & $22.15 \pm 0.56$ & $<0.0001^{*}$ & $24.0-46.0$ \\
$\mathrm{Hb}(\mathrm{g} / \mathrm{L})$ & $9.09 \pm 0.09$ & $7.13 \pm 0.09$ & $<0.0001^{*}$ & $8.0-15.0$ \\
$\mathrm{MCV}(\mathrm{fL})$ & $50.60 \pm 0.43$ & $49.94 \pm 0.65$ & 0.291 & $40-60^{* *}$ \\
$\mathrm{MCH}(\mathrm{pg})$ & $15.65 \pm 0.23$ & $16.67 \pm 0.35$ & $0.002^{*}$ & $11.0-17.0^{* *}$ \\
$\mathrm{MCHC}(\mathrm{g} / \mathrm{L})$ & $312.40 \pm 2.30$ & $318.10 \pm 3.40$ & 0.083 & $300-360^{* *}$ \\
RDW $(\%)$ & $16.54 \pm 0.14$ & $16.99 \pm 0.21$ & $0.032^{*}$ & $16.7-23.3^{* *}$ \\
Platelets $\left(\times 10^{9} / \mathrm{L}\right)$ & $349.96 \pm 2.24$ & $374.224 \pm 6.20$ & $0.021^{*}$ & $100-800^{* *}$ \\
Cholesterol $(\mathrm{mmol} / \mathrm{L})$ & $2.46 \pm 0.08$ & $2.11 \pm 0.16$ & $0.043^{*}$ & $1.0-5.6^{* *}$ \\
BHBA $(\mathrm{mmol} / \mathrm{L})$ & $0.44 \pm 0.18$ & $0.99 \pm 0.15$ & $0.042^{*}$ & $0.35-0.47^{* *}$ \\
NEFA $(\mathrm{mmol} / \mathrm{L})$ & $0.41 \pm 0.10$ & $0.94 \pm 0.20$ & $0.023^{*}$ & $<0.700^{* * *}$ \\
Fibrinogen $(\mathrm{g} / \mathrm{L})$ & $2.50 \pm 0.40$ & $4.40 \pm 1.00$ & $0.049^{*}$ & $2.0-7.0^{* *}$ \\
Albumin $(\mathrm{g} / \mathrm{L})$ & $31.74 \pm 0.42$ & $30.09 \pm 0.78$ & $0.061^{*}$ & $29-38^{* *}$ \\
Globulin $(\mathrm{g} / \mathrm{L})$ & $32.20 \pm 2.0$ & $38.70 \pm 2.70$ & $0.031^{*}$ & $30.0-34.8^{* * * *}$ \\
Calcium $(\mathrm{mmol} / \mathrm{L})$ & $2.49 \pm 0.02$ & $2.19 \pm 0.03$ & $0.023^{*}$ & $2.43-3.10^{* *}$ \\
TBIL $(\mu \mathrm{mol} / \mathrm{L})$ & $4.45 \pm 1.20$ & $3.42 \pm 0.68$ & 0.101 & $0.7-7.54^{* *}$ \\
\hline
\end{tabular}

"Denotes significance at $\mathrm{P}<0.05 ;{ }^{* *}$ Reference value according to Radostits et al. (2007); ${ }^{* * *}$ Reference value according to Kaneko et al. (2008); ${ }^{* * * *}$ Reference value according to Drackley (2000)

The current study characterises the prevalence of anaemia in dairy cows during the puerperium, as well as the haematological and biochemical profiles of the cows evaluated.

It could not be demonstrated that inflammation of the uterus (cows with metritis and endometritis), mammary gland (mastitis) and the locomotor system (lame cows) would be associated with increased prevalence of anaemia during the puerperium. Lower values of RBC and $\mathrm{Ht}$ were found in cows with subclinical endometritis, which finding was related to the production of inflammatory cytokines (Heidarpour et al., 2014).

Cows with high milk production were more likely to have metabolic disease (Asl et al., 2011). Previous studies have shown an increase in the prevalence of puerperal and metabolic diseases in dairy cows with increased parity numbers (Asl et al., 2011; Neves et al., 2018). Regarding BCS, Carneiro et al. (2014) suggested an increase in the incidence of endometritis in dairy cows with a body condition score $\leq 2.5$. In our study, neither of these factors were associated with the occurrence of anaemia.

During the puerperal period, haematological and biochemical changes were described in dairy cows with retained fetal membranes (Saut and Birgel, 2008; Paiano et al., 2018; Paiano et al., 2019a). However, such changes have not been described in dairy cows with anaemia during the puerperium. 
The blood smears did not show intra-erythrocytic parasites, and the total bilirubin values were within the normal range; this result ruled out the possibility that the anaemia resulted from haemolysis caused by haemoparasites (Souza et al., 2013).

Transition cows undergo a period of negative energy balance, which may contribute to the onset of inflammation processes during this stage, varying in intensity from animal to animal (Contreras and Sordillo, 2011). During the inflammatory process the production of pro-inflammatory cytokines may be increased; these cytokines help modulate the inflammatory response since they inhibit erythropoiesis through the action of erythroid precursors (Chikazawa and Dunning, 2016). The exacerbated pro-inflammatory state may lead to the suppression of erythropoiesis due to the direct effects of cytokines on the bone marrow; this process limits the erythropoietic response to erythropoietin, which becomes insufficient to compensate for the destruction of erythrocytes, thus leading to reduced haematological values and the onset of anaemia (Nemeth and Ganz, 2014). Supporting this explanation of anaemia due to the presence of an inflammatory process, our data are in agreement with this hypothesis due to an increase in the concentration of fibrinogen and globulin in anaemic animals. Fibrinogen and globulin are considered acute phase proteins, and cholesterol is considered a negative acute phase reactant; the monitoring of these parameters can be used for evaluating the intensity of inflammatory processes (Jain, 1993; Trevisi et al., 2015; Paiano et al., 2019b). In addition, low serum concentrations of calcium and cholesterol, and high concentrations of globulin have been described in dairy cows with inflammatory processes (Trevisi et al., 2015). Furthermore, the evaluation of albumin levels contributes to understanding the inflammatory status of the animals. Albumin is considered an acute phase negative protein, and low albumin levels have been correlated with severe inflammation in transition dairy cows (Bionaz et al., 2007). The albumin value recorded in the present study shows a decreasing trend in anaemic cows.

In agreement with a previous report (Trevisi et al., 2015), our results indicate that energy imbalance may have resulted in anaemia in dairy cows during the early postpartum period, mainly due to low serum cholesterol levels associated with high BHBA and NEFA levels.

In conclusion, the current study shows that anaemia is prevalent during the puerperium in Holstein dairy cows. In addition, our results indicate changes in the energy balance of anaemic animals, as well as a pro-inflammatory state in this group of cows.

\section{Acknowledgements}

The authors thank the veterinarians Ana Elisa Negrão Pereira Barreto, João Padilha Gandara Mendes, Artur Vilas Boas Costa, Camila Gabriela Vaquero, Francisco 
Palma Rennó, Guilherme Gomes da Silva and the staff of the farm for use of their cows and facilities. This study was financed in part by the Coordenação de Aperfeiçoamento de Pessoal de Nível Superior - Brasil (CAPES) - Finance Code 001.

\section{References}

Asl, A. N., Nazifi, S., Ghasrodashti, A. R. and Olyaee, A. (2011): Prevalence of subclinical ketosis in dairy cattle in the Southwestern Iran and detection of cutoff point for NEFA and glucose concentrations for diagnosis of subclinical ketosis. Prev. Vet. Med. 100, 38-43.

Bionaz, M., Trevisi, E., Calamari, L., Librandi, F., Ferrari, A. and Bertoni, G. (2007): Plasma paraoxonase, health, inflammatory conditions, and liver function in transition dairy cows. J. Dairy Sci. 90, 1740-1750.

Birgel, E. H. (1982): Hematologia clínica veterinária. In: Birgel, E. H. and Benesi, F. J. (eds) Patologia Clínica Veterinária. Sociedade Paulista de Medicina Veterinária, São Paulo. 346 pp.

Carneiro, L. C., Ferreira, A. F., Padua, M., Saut, J. P., Ferraudo, A. S. and Dos Santos, R. M. (2014): Incidence of subclinical endometritis and its effects on reproductive performance of crossbred dairy cows. Trop. Anim. Health Prod. 46, 1435-1439.

Chikazawa, S. and Dunning, M. D. (2016): A review of anaemia of inflammatory disease in dogs and cats. J. Small Anim. Pract. 57, 348-353.

Contreras, A. G. and Sordillo, L. M. (2011): Lipid mobilization and inflammatory responses during the transition period of dairy cows. Comp. Immunol. Microbiol. Infect. Dis. 34, 281-289.

Drackley, J. K. (2000): Use of NEFA as a tool to monitor energy balance in transition dairy cows. Illinois Dairy Days.

Ferguson, J. D., Galligan, D. T. and Thomsen, N. (1994): Principal descriptors of body condition score in Holstein cows. J. Dairy Sci. 77, 2695-2703.

Heidarpour, M., Mohri, M., Fallah-Rad, A. H., Dehghan, F. and Shahreza, M. M. (2014): Hematological changes before and after treatment in dairy cows with clinical and subclinical endometritis. Comp. Clin. Pathol. 23, 97-101.

Jain, N. C. (1993): Essentials of Veterinary Haematology. Lea and Febiger, Pennsylvania. 989 pp.

Kaneko, J. J., Harvey, J. W. and Bruss, M. L. (2008): Clinical Biochemistry of Domestic Animals. 6th edition. Academic Press, San Diego. 916 pp.

Lindt, F. and Blum, J. W. (1994): Occurrence of iron deficiency in growing cattle. Zentralbl. Veterinarmed. A 41, 237-246.

McDougall, S., Macaulay, R. and Compton, C. (2007): Association between endometritis diagnosis using a novel intravaginal device and reproductive performance in dairy cattle. Anim. Reprod. Sci. 99, 9-23.

Muntean, V-I., Sárpataki, O., Potârniche, A-V., Meghzili, H., Sevastre, B. and Marcus, I. (2018): Calculation of the required transfusion volume in anaemic Holstein calves. Acta Vet. Hung. 66, 542-552.

Nemeth, E. and Ganz, T. (2014): Anemia of inflammation. Hematol. Oncol. Clin. North Am. 28, 671-681.

Neves, R. C., Leno, B. M., Curler, M. D., Thomas, M. J., Overton, T. R. and McArt, J. A. A. (2018): Association of immediate postpartum plasma calcium concentration with earlylactation clinical diseases, culling, reproduction, and milk production in Holstein cows. J. Dairy Sci. 101, 547-555.

Paiano, R. B.; Lahr, F. C., Poit, D. A. S., Costa, A. G. B. V. B., Birgel, D. B. and Birgel Junior, E. H. (2018): Biochemical profile in dairy cows with artificial induction of lactation. Pesq. Vet. Bras. 38, 2289-2292. 
Paiano, R. B., Birgel, D. B. and Birgel Junior, E. H. (2019a): Uterine involution and reproductive performance in dairy cows with metabolic diseases. Animals 9, 93.

Paiano, R. B., Gonçalves, C. G. P., Mendes, J. P. G., Bonilla, J., Birgel, D. B. and Birgel Junior, E. H. (2019b): Comparative biochemical profiles, production and reproduction status of the postpartum dairy cows with and without purulent vaginal discharge. Reprod. Domest. Anim. doi: 10.1111/rda.13496 [Epub ahead of print].

Radostits, O. M., Gay, C. C., Hinchcliff, K. W. and Constable, P. D. (2007): Reference laboratory values. In: Veterinary Medicine. A Textbook of the Diseases of Cattle, Sheep, Goats, Pigs and Horses. 10th ed. Saunders Elsevier, St. Louis, MO, USA. pp. 2047-2050.

Ribeiro, E. S., Lima, F. S., Greco, L. F., Bisinotto, R. S., Monteiro, A. P. A., Favoreto, M., Ayres, H., Marsola, R. S., Martinez, N., Thatcher, W. W. and Santos, J. E. P. (2013): Prevalence of periparturient diseases and effects on fertility of seasonally calving grazing dairy cows supplemented with concentrates. J. Dairy Sci. 96, 5682-5697.

Saut, J. P. E. and Birgel Junior, E. H. (2008): The influence of retained fetal membranes on the hemogram of Holstein cows. Arq. Bras. Med. Vet. Zootec. 60, 1315-1322.

Sheldon, I. M., Cronin, J., Goetze, L., Donofrio, G. and Schuberth, H. (2009): Defining postpartum uterine disease and the mechanisms of infection and immunity in the female reproductive tract in cattle. Biol. Reprod. 81, 1025-1032.

Souza, F. A. L., Braga, J. F. V., Pires, L. V., Carvalho, C. J. S., Costa, E. A., Ribeiro, M. F. B., Santos, R. L. and Silva, S. M. M. S. (2013): Babesiosis and anaplasmosis in dairy cattle in Northeastern Brazil. Pesqui. Vet. Bras. 33, 1057-1061.

Trevisi, E., Jahan, N., Bertoni, G., Ferrari, A. and Minuti, A. (2015): Pro-inflammatory cytokine profile in dairy cows: consequences for new lactation. Ital. J. Anim. Sci. 14, 285-292.

Thrusfield, M. (2005): Veterinary Epidemiology. 2nd edition. Blackwell Science Ltd., London. pp. $182-198$. 